\title{
Uji Daya Hasil Klon Harapan Kentang (Solanum tuberosum L.) IPB di Kabupaten Garut Jawa Barat
}

\section{Yield Trials of IPB Potato (Solanum tuberosum L.) Promising Lines in Garut District West Java}

\author{
Dicky Hasian Zulkarnain, Awang Maharijaya*, Muhamad Syukur \\ Departemen Agronomi dan Hortikultura, Fakultas Pertanian, Institut Pertanian Bogor \\ Jalan Meranti, Kampus IPB Dramaga, Bogor 16680, Indonesia \\ *Penulis untuk korespondensi. email: awang.maharijaya@gmail.com
}

Diterima 19 November 2016/Disetujui 9 Januari 2017

\begin{abstract}
Potatoes (Solanum tuberosum L.) highly consumed in the form of vegetable and processed potato so that the needs of potatoes have not been fulfilled by domestic production. One effort to increase national potato production is to assemble high-yield varieties of potato. This study aimed to test the production of several IPB potato promising clones. This research was conducted in Garut, West Java in May to August 2016. This research used Completely Randomized Design with clone as the factor and repetition as many as three replications as the group. The planting material used was IPB Potato promising clones which consisted of PKHT 2, PKHT 4, PKHT 6, PKHT 9, and PKHT 10 and Granola and Atlantik as the comparison. The results showed that PKHT 4, PKHT 6, PKHT 9, and PKHT 10 are IPB potato promising clones that have high production equivalent to Granola and higher than Atlantik as commercial varieties. Based on physical criteria PKHT 4 and PKHT 6 suitable to be processed potato chips and PKHT 9 and PKHT 10 suitable to be vegetable potato.
\end{abstract}

Keywords: atlantic, granola, potato as vegetable, processed potato

ABSTRAK

Kentang (Solanum tuberosum L.) banyak dikonsumsi dalam bentuk sayur dan olahan sehingga kebutuhan kentang nasional belum mampu dipenuhi oleh produksi kentang dalam negeri. Salah satu upaya untuk meningkatkan produksi kentang nasional adalah dengan merakit varietas kentang berdaya hasil tinggi. Penelitian ini bertujuan untuk menguji produksi beberapa klon harapan kentang IPB. Penelitian ini dilakukan di Garut, Jawa Barat pada bulan Mei sampai Agustus 2016. Penelitian ini menggunakan Rancangan Kelompok Lengkap Teracak dengan klon sebagai faktornya dan ulangan sebanyak tiga ulangan sebagai kelompok. Bahan tanam yang digunakan adalah klon harapan kentang IPB yang terdiri dari PKHT 2, PKHT 4, PKHT 6, PKHT 9, dan PKHT 10 serta Granola dan Atlantik sebagai pembandingnya. Hasil penelitian menunjukkan bahwa PKHT 4, PKHT 6, PKHT 9, dan PKHT 10 adalah klon-klon kentang harapan IPB yang memiliki produksi yang setara dengan Granola dan lebih tinggi dibandingkan dengan Atlantik sebagai varietas komersial. Berdasarkan kriteria fisik PKHT 4 dan PKHT 6 cocok untuk dijadikan kentang olahan chips dan PKHT 9 dan PKHT 10 cocok untuk dijadikan kentang sayur.

Kata kunci: atlantik, granola, kentang olahan, kentang sayur

\section{PENDAHULUAN}

Kentang (Solanum tuberosum L.) dibudidayakan di Indonesia di kawasan dengan elevasi 900 sampai 2,000 meter di atas permukaan laut. Rata-rata suhu udara tahunan di kawasan tersebut bervariasi, antara minimum $12.2^{\circ} \mathrm{C}$ dan $17.5^{\circ} \mathrm{C}$, sedangkan maksimum antara $15.1^{\circ} \mathrm{C}$ dan $18.9^{\circ} \mathrm{C}$. Rata-rata curah hujan yang ideal untuk pertanaman kentang adalah 1,800 mm sampai 3,500 mm (Hadisoeganda, 2006).

Produksi kentang nasional mengalami fluktuasi dari tahun 2010 hingga 2014. Produksi kentang nasional pada 2010 adalah $1,060,805$ ton dan mengalami penurunan produksi pada 2011 menjadi 955,488 ton namun terus mengalami peningkatan jumlah produksi sejak 2012 yaitu
$1,094,232$ ton, $1,124,282$ ton pada 2013 dan mencapai $1,347,815$ ton pada tahun 2014 (Kementerian Pertanian, 2015). Fluktuasi juga terjadi pada jumlah konsumsi kentang per kapita dalam setahun sejak 2012 hingga 2015 yaitu 1.460 $\mathrm{kg} \mathrm{kapita}^{-1}, 1.564 \mathrm{~kg} \mathrm{kapita}^{-1}$ dan mengalami penurunan pada 2014 menjadi $1.460 \mathrm{~kg} \mathrm{kapita}^{-1}$ dan mengalami peningkatan cukup signifikan hingga $2.294 \mathrm{~kg} \mathrm{kapita}^{-1}$ (Pusdatin, 2016).

Pemanfaatan kentang dibagi menjadi dua, yaitu kentang sayur dan kentang. Hal ini mengakibatkan konsumsi kentang menjadi tinggi. Konsumsi kentang yang cukup tinggi tidak dapat dipenuhi oleh produksi kentang nasional. Salah satu cara dalam pemenuhan permintaan kentang nasional adalah impor kentang dari negara lain dengan nilai impor yang mencapai 5,831,022 US dolar pada tahun 2014. Jenis 
kentang yang dominan dikirim ke Indonesia adalah kentang olahan dibandingkan kentang segar dengan nilai 59,416,872 US dolar untuk kentang olahan dan 23,824,048 US dolar untuk kentang segar sejak Januari hingga Desember 2014 (Kementerian Pertanian, 2015). Tingginya nilai impor ini dapat dikurangi dengan peningkatan produksi kentang dalam negeri.

Permasalahan utama kentang di Indonesia adalah penyediaan benih unggul. Kultivar yang umum digunakan masyarakat adalah Granola yang berasal dari Jerman dan Atlantik yang berasal dari Amerika Serikat. Granola memiliki keunggulan dalam umur pendek, hasil cukup tinggi, bentuk umbi yang bagus, tahan penyakit virus PVX dan PVY, agak tahan hawar daun dan penyakit layu. Kelemahannya adalah memiliki kadar air yang cukup tinggi dan tidak cocok untuk kentang olahan. Kentang kultivar Atlantik berumur pendek, tahan penyakit PVX, mutu umbi sangat baik, bahan kering tinggi, dan sangat baik dijadikan chips dan fries. Kelemahannya adalah peka terhadap virus PVY, hawar daun, dan penyakit layu bakteri (Purwito dan Wattimena, 2008).

Ketidaktersediaannya benih unggul hasil rakitan Indonesia mengakibatkan kentang yang ditanam memiliki produktivitas yang lebih rendah dibandingkan potensi hasil yang dapat dicapai. Tidak adanya kentang berproduksi tinggi disebabkan oleh kentang yang digunakan pada umumnya bukanlah kentang varietas lokal. Granola adalah varietas yang mendominasi pertanaman kentang di Indonesia, yaitu antara $80-90 \%$ (Prabaningrum et al., 2015). Produktivitas kentang nasional Indonesia pada tahun 2015 adalah 18.20 ton $\mathrm{ha}^{-1}$ (Kementerian Pertanian, 2016).

Salah satu upaya untuk meningkatkan produktivitas kentang adalah dengan perakitan varietas kentang berdaya hasil tinggi. Serangkaian penelitian telah dilakukan di IPB untuk menyeleksi genotipe kentang unggul termasuk untuk ketahanannya terhadap penyakit utamanya (Maharijaya et al., 2008). Penelitian tentang produktivitas klon harapan kentang yang ada sebagai upaya pengadaan benih lokal sangat penting untuk dilakukan. Hal ini akan memberikan alternatif penyediaan benih kentang unggul sebagai bahan tanam lokal. Tujuan penelitian ini adalah mengevaluasi daya hasil klon harapan kentang IPB di Garut, Jawa Barat.

\section{BAHAN DAN METODE}

Penelitian ini dilaksanakan di Desa Cikajang, Kabupaten Garut, Jawa Barat. Penelitian ini dilakukan pada bulan Mei sampai dengan Agustus 2016. Bahan yang akan digunakan pada penelitian ini yaitu kentang hasil persilangan yang terdiri atas PKHT 2, PKHT 4, PKHT 6, PKHT 9, dan PKHT 10, serta Atlantik dan Granola sebagai varietas pembanding.

Rancangan yang digunakan dalam penelitian ini adalah Rancangan Kelompok Lengkap Teracak dengan lima galur kentang harapan dan dua varietas komersial sebagai pembanding. Setiap perlakuan diulang sebanyak tiga kali sehingga terdapat 21 satuan percobaan, dengan setiap satuan percobaan terdiri dari 12 tanaman. Faktor yang digunakan dalam penelitian ini adalah galur.
Penelitian dimulai dengan memilih umbi yang berkualitas baik sebagai bahan tanam. Pertanaman disesuaikan dengan kebiasaan petani pada umumnya agar tidak terjadi bias hasil antara penelitian dengan pertanaman petani. Pengamatan dilakukan terhadap lima tanaman contoh pada masing-masing satuan percobaan. Peubah yang diamati adalah jumlah serangan organisme pengganggu tanaman (OPT), tinggi tanaman $(\mathrm{cm})$, diameter batang (mm), jumlah cabang, jumlah daun, jumlah umbi, bobot satuan umbi per tanaman (g), dan bobot umbi per tanaman (g). Pengamatan juga dilakukan pada umbi layak pasar. Pengamatan dilakukan saat umur tanaman 14, 28, 35, 42, $56,70,84,91$ hari setelah tanam dan setelah panen.

\section{HASIL DAN PEMBAHASAN}

\section{Jumlah Serangan OPT}

Organisme pengganggu tanaman (OPT) utama yang ada pada pertanaman adalah Virus PVY, Phytophthora infestans, dan Ralstonia solanacearum. Tingginya serangan OPT pada tanaman diindikasikan selain faktor generasi bibit yang sudah mencapai G4 juga karena kondisi lingkungan yang mendukung, yaitu seringnya terjadi hujan pada sore hari selama pertanaman. Tingginya intensitas hujan mendukung berkembang dan menyebarnya organisme penggnggu tanaman dengan cepat. Serangan virus PVY tidak berbeda nyata pada setiap klon/varietas (Tabel 1). Infeksi virus yang terjadi pada pertanaman kentang ada yang secara tunggal dan berasosiasi dengan gejala mosaik sehingga sulit untuk dibedakan. Klon/varietas pada pertanaman mengalami gejala malformasi daun yaitu daun yang menggulung dengan ukuran yang lebih kecil.

Gejala serangan $P$. infestans terlihat pada batang dan daun yang menghitam karena terjadi pembusukan lunak. Serangan berat oleh $P$. infestans mengakibatkan tanaman mengering seluruhnya dan mengalami kematian. Menurut Purwanti (2002) gejala serangan awal oleh P. infestans terdapat pada daun dan pada pada infeksi yang berat. seluruh bagian tanaman akan membusuk hingga tanaman mati. Varietas Atlantik adalah satu-satunya yang terinfeksi oleh P.infestans (Tabel 1). Hal ini diindikasikan karena sifat genetik Atlantik yang tidak tahan serangan $P$. infestans serta umbi yang sudah mencapai generasi ke-4 (G4) dan didukung oleh intensitas hujan tinggi yang mendukung perkembangan dan penyebaran $P$. infestans secara cepat. Atlantik terinfeksi serangan berat $P$. infestans sampai mengakibatkan batang dan daun menjadi busuk kehitaman.

Serangan $R$. Solanacearum mengakibatkan kentang terinfeksi penyakit layu bakteri. Penyakit ini pada taraf serangan berat dapat mengakibatkan busukumbi(Asgar et al., 2011). Klon yang paling banyak terserang $R$. Solanacearum adalah PKHT 6 dan tidak berbeda nyata secara statistik dengan varietas pembanding Granola. Gejala dari tanaman yang terserang $R$. solanacearum adalah layu pada bagian daun muda dan terus menjalar sampai ke batang. Varietas Atlantik tidak ada yang diamati untuk penyakit layu bakteri. Hal ini disebabkan oleh varietas Atlantik yang sudah rusak pertanamannya oleh $P$. infestans terlebih dahulu. Salah satu 
Tabel 1. Daya tumbuh, tinggi tanaman, jumlah daun, dan jumlah serangan OPT

\begin{tabular}{|c|c|c|c|c|}
\hline \multirow[b]{2}{*}{ Klon } & \multirow[b]{2}{*}{ Daya tumbuh } & \multicolumn{3}{|c|}{ Jumlah serangan OPT } \\
\hline & & Potato Virus $Y$ & $\begin{array}{c}\text { Phytophthora } \\
\text { infestans }\end{array}$ & $\begin{array}{c}\text { Ralstonia } \\
\text { solanacearum }\end{array}$ \\
\hline PKHT 2 & 100.00 & 55.56 & $0.00 \mathrm{~b}$ & $0.00 \mathrm{~b}$ \\
\hline PKHT 4 & 99.07 & 50.00 & $0.00 \mathrm{~b}$ & $0.00 \mathrm{~b}$ \\
\hline PKHT 6 & 86.11 & 33.33 & $0.00 \mathrm{~b}$ & $47.22 \mathrm{a}$ \\
\hline РКHT 9 & 97.22 & 36.11 & $0.00 \mathrm{~b}$ & $2.78 \mathrm{~b}$ \\
\hline PKHT10 & 86.11 & 44.44 & $0.00 \mathrm{~b}$ & $5.56 \mathrm{~b}$ \\
\hline Atlantik & 69.44 & 19.44 & $38.89 \mathrm{a}$ & - \\
\hline Granola & 100.00 & 55.56 & $0.00 \mathrm{~b}$ & $22.22 \mathrm{ab}$ \\
\hline Uji F & $\operatorname{tn}$ & $\operatorname{tn}$ & $* *$ & $* *$ \\
\hline
\end{tabular}

Keterangan: Angka yang diikuti huruf sama pada kolom tidak berbeda nyata pada DMRT taraf $\alpha=0.05$, tn=tidak berpengaruh nyata pada uji F 95\%, OPT= Organisme Penganggu Tanaman, **= berpengaruh nyata pada taraf $1 \%$

solusi yang masih dilakukan peneliti adalah mendapatkan varietas tahan akan serangan OPT. salah satunya dengan mencari kerabat liar yang tahan. Maharijaya (2014) melaporkan bahwa kentang memiliki kerabat liar seperti $S$. berhaultii, S. tarjinense, S. piurae, S. okadae, S. chacoense, S. stenotonum yang memiliki ketahanan tinggi terhadap serangan OPT.

\section{Karakter Vegetatif}

Klon PKHT 9 adalah tanaman yang memiliki rata-rata tinggi paling besar yaitu $60.60 \mathrm{~cm}$. namun tidak berbeda nyata dengan PKHT 2, PKHT 4, PKHT 6, PKHT 9, РKHT 10 dan varietas Granola sebagai pembanding secara statistik. Tinggi tanaman kentang berhubungan dengan penggunaan ajir. Kentang merupakan tanaman herba (tidak berkayu), sehingga dalam budidayanya dibutuhkan ajir agar tanaman tetap tegak. Tanaman kentang yang baik adalah kentang yang tidak terlalu tinggi, sehingga dapat meminimalisir kemungkinan terjadinya roboh (Hidayat. 2014). Tanaman kentang yang terlalu tinggi akan menyulitkan dalam pemasangan ajir. Atlantik adalah satu-satunya klon yang tidak membutuhkan ajir selama pertanaman karena keragaan Atlantik yang rendah, sedangkan klon/varietas lain diberikan ajir untuk mencegah terjadinya roboh saat pertumbuhan.

Diameter batang tanaman kentang juga berhubungan dengan kerobohan tanaman. Kisaran diameter tanaman kentang dari 7 klon/varietas adalah 8.00-10.80 mm (Tabel 2) dan tidak berbeda nyata secara statistik. Diameter batang yang cukup besar akan mendukung tegaknya pertanaman klon/varietas kentang. Hidayat (2014) melaporkan bahwa selain tinggi tanaman. diameter batang adalah salah satu penentu robohnya pertanaman kentang. Berdasarkan keadaan lapang, tidak ada tanaman yang mengalami roboh. Hal ini dikarenakan diameter batang masih cukup berimbang dengan tinggi tanaman klon/varietas.

Kisaran jumlah cabang pada klon/varietas kentang yang ditanaman adalah 6.00-11.82 cabang per tanaman (Tabel 2). PKHT 6 adalah klon yang memiliki jumlah cabang terbanyak yaitu 11.82 cabang per tanaman namun tidak berbeda nyata secara statistik dengan PKHT 2, PKHT 4, PKHT 9, PKHT 10 dan varietas pembanding Granola. Varietas Atlantik memiliki jumlah cabang paling sedikit yaitu 6.00 cabang per tanaman. namun tidak berbeda nyata

Tabel 2. Tinggi tanaman, diameter batang, jumlah cabang, dan jumlah daun pada tanaman kentang

\begin{tabular}{lcccc}
\hline Klon & Tinggi tanaman $(\mathrm{cm})$ & Diameter batang $(\mathrm{mm})$ & Jumlah cabang & Jumlah daun \\
\hline PKHT 2 & $49.93 \mathrm{a}$ & 8.57 & $8.87 \mathrm{ab}$ & $74.27 \mathrm{a}$ \\
PKHT 4 & $53.00 \mathrm{a}$ & 10.61 & $9.53 \mathrm{ab}$ & $78.07 \mathrm{a}$ \\
PKHT 6 & $58.16 \mathrm{a}$ & 10.8 & $11.82 \mathrm{a}$ & $73.97 \mathrm{a}$ \\
PKHT 9 & $60.60 \mathrm{a}$ & 9.66 & $8.53 \mathrm{ab}$ & $75.40 \mathrm{a}$ \\
PKHT10 & $60.47 \mathrm{a}$ & 9.68 & $11.07 \mathrm{ab}$ & $74.40 \mathrm{a}$ \\
Atlantik & $28.00 \mathrm{~b}$ & 8.00 & $6.00 \mathrm{~b}$ & $32.67 \mathrm{~b}$ \\
Granola & $51.53 \mathrm{a}$ & 8.12 & $8.07 \mathrm{ab}$ & $64.87 \mathrm{a}$ \\
Uji F & $*$ & tn & $*$ & $* *$ \\
\hline
\end{tabular}

Keterangan: Angka yang diikuti huruf sama pada kolom tidak berbeda nyata pada DMRT taraf $\alpha=5 \%$, th $=$ tidak berpengaruh nyata pada taraf $5 \%, *=$ berpengaruh nyata pada taraf $5 \%, * *=$ berpengaruh nyata pada taraf $1 \%$ 
secara statistik dengan PKHT 2, PKHT 4, PKHT 9, dan PKHT 10, Jumlah cabang yang sedikit dapat terjadi karena genetika tanaman dan serangan hama dan penyakit. Selama pertanaman diketahui bahwa terjadi serangan penyakit yang juga mengakibatkan jumlah cabang tanaman menjadi sedikit. Hal tersebut terjadi pada varietas Atlantik yang memiliki diameter batang kecil sebagai akibat kebusukan pangkal batang, sehingga cabang tidak dapat tumbuh optimal pada batang utama tanaman. Hal ini berakibat pada Atlantik yang memiliki jumlah cabang paling sedikit diantara klon/varietas yang lain dalam satu pertanaman. Tanaman kentang yang diharapkan adalah tanaman kentang dengan jumlah cabang yang banyak.

Daun kentang yang diharapkan adalah daun dengan jumlah yang banyak sehingga dapat menghasilkan fotosintat yang maksimal. Kisaran rata-rata jumlah daun klon/varietas pada penelitian ini adalah 32.67-78.07 daun untuk setiap tanaman. Berdasarkan pengamatan, secara statistik PKHT 2, PKHT 4, PKHT 6, PKHT 9 dan PKHT 10 memiliki jumlah daun yang tidak berbeda nyata dengan varietas pembanding Granola dan lebih banyak dibandingkan varietas Atlantik. Jumlah daun terbanyak adalah PKHT 4 sebanyak 78.07 diikuti PKHT 9 dengan 75.40 daun, PKHT 10 dengan 74.40 daun, PKHT 2 dengan 74.27 daun, dan PKHT 6 dengan 73.97 daun. Varietas Atlantik memiliki rata-rata jumlah daun terendah dalam pengamatan dan berbeda nyata dengan semua klon/varietas. Jumlah daun Atlantik hanya 32.67 daun, sedangkan Granola sebagai varietas pembanding juga memiliki rata-rata jumlah daun sebanyak 64.87 daun. Jumlah daun yang diharapkan adalah tanaman dengan jumlah daun yang banyak karena daun berfungsi untuk menghasilkan fotosintat yang disimpan dalam umbi. Menurut Pertamawati (2010) Daun merupakan organ utama yang sangat penting dalam proses fotosintesis.

\section{Komponen dan Hasil Panen}

Kentang merupakan tanaman determinate yang hanya dapat sekali dipanen dalam satu siklus hidupnya. Pemanenan kentang pada umumnya dilakukan pada saat kentang sudah berumur 90-120 hari setelah tanam (Nonnecke, 1989). Pemanenan untuk galur/varietas kentang pada penelitian ini dilakukan pada umur 91 hari setelah tanam. Pemanenan di umur panen awal ini dikarenakan adanya serangan hama, sehingga proses pemanenan harus segera dilakukan untuk menghindari kehilangan hasil yang lebih besar. Kondisi pertanaman kentang sudah memasuki umur panen ditandai dengan mulai mengeringnya bagian daun dan batang. Menurut Hamdani (2009) keadaan tanaman kentang yang sudah siap panen adalah kentang yang memiliki batang dan daun menguning dan rontok.

Secara keseluruhan total umbi terbanyak adalah PKHT 10 diikuti PKHT 9 namun tidak berbeda nyata dengan PKHT 6 dan PKHT 4 serta varietas pembanding Granola. Kedua klon yang ditargetkan sebagai kentang sayur ini memiliki potensi menghasilkan rata-rata jumlah umbi yang cukup tinggi antara 10.27-10.53 umbi per tanaman dan tidak berbeda nyata dengan varietas pembanding Granola.
PKHT 4 dan PKHT 6 yang ditargetkan sebagai kentang olahan juga memiliki jumlah umbi yang nyata lebih banyak dibandingkan varietas Atlantik sebagai varietas pembanding. Hal ini dapat menjadi alternatif petani dalam memilih kentang olahan yang memiliki jumlah umbi lebih banyak dibandingkan dengan varietas Atlantik yang dominan di masyarakat. Varietas Atlantik hanya menghasilkan umbi sebanyak 3.10 per tanaman sedangkan PKHT 4 dan PKHT 6 memiliki umbi masing-masing 7.33 dan 9.31 umbi per tanaman. Struik dan Wiersema (1999) menyatakan bahwa jumlah stolon dipengaruhi oleh kecukupan nutrisi, ukuran bibit, kelembaban tanah, kedalaman tanah dan varietas.

Bobot satuan menjadi penting terutama untuk kentang olahan. Hal ini disebabkan oleh standar yang dimiliki oleh industri kentang yang bisa diolah. Budiman (1999) menyatakan bahwa bobot satuan umbi berhubungan dengan penggunaan kentang sebagai kentang goreng. yaitu 170-284 gram per umbi dan bentuk yang memanjang. Berdasarkan Tabel 4, PKHT 6 dan PKHT 4 adalah kentang yang ditargetkan untuk menjadi kentang olahan dan juga merupakan klon dengan bobot satuan terbaik dan berbeda nyata dengan varietas pembanding Atlantik. Nilai bobot satuan klon PKHT 4 dan PKHT 6 belum mampu memenuhi kriteria bobot satuan untuk penggunaan kentang goreng. namun Klon PKHT 4 dan PKHT 6 memenuhi kriteria bentuk umbi yang memanjang sebagai kriteria kentang goreng yang lain.

Bobot satuan tidak mempunyai fungsi spesifik dalam kentang sayur. Bobot satuan yang besar pada kentang sayur hanya akan meningkatkan nilai jual karena dianggap memiliki kualitas yang lebih baik. Bobot satuan Granola sebagai varietas pembanding masih tetap menjadi yang terbaik namun tidak berbeda nyata dengan klon PKHT 9 dan PKHT 10 dan berbeda nyata dengan PKHT 2. Bobot satuan tinggi menjadi salah satu alasan petani memilih Granola sebagai kentang yang banyak ditanam. Petani mengharapkan 70-80\% kentang memiliki bobot satuan $>60$ gram (Wulandari et al., 2014) dan Granola dapat memenuhi ekspektasi petani. Berdasarkan penelitian ini didapatkan PKHT 9 dan PKHT 10 yang memiliki bobot satuan yang tidak berbeda nyata dengan Granola dan diharapkan dapat menjadi substitusi Granola sebagai kentang sayur.

Sebaran bobot total umbi seluruh klon/varietas antara 139.37-797.40 gram per lubang tanaman (Tabel 3). Bobot total yang tinggi adalah hasil yang ingin dicapai dalam setiap pertanaman kentang. PKHT 9 sebagai klon yang ditargetkan menjadi kentang sayur memiliki bobot total yang paling tinggi secara keseluruhan dan tidak berbeda nyata dengan PKHT 4 dan PKHT 6. Total umbi yang tinggi pada PKHT 9 dan berbeda sangat nyata dengan varietas pembanding Granola mengindikasikan bahwa PKHT 9 dapat menjadi alternatif unggul varietas Granola. Granola yang umumnya ditanam oleh petani karena produksi yang tinggi dapat disubstitusi oleh PKHT 9 yang lebih baik dan PKHT 10 yang memiliki bobot total yang tidak berbeda nyata.

PKHT 4 dan PKHT 6 adalah kentang dengan bobot total terbaik pada kategori kentang olahan yaitu 697.22 gram dan 718.04 gram per tanaman dan berbeda sangat 
Tabel 3. Jumlah umbi, bobot satuan umbi, dan bobot total umbi pada tanaman kentang

\begin{tabular}{|c|c|c|c|c|}
\hline Klon & Jumlah umbi & Bobot satuan (g) & Bobot total (g) & $\begin{array}{c}\text { Produktivitas } \\
\left(\text { ton } \mathrm{ha}^{-1}\right)\end{array}$ \\
\hline \multicolumn{5}{|c|}{ Kentang sayur } \\
\hline Granola & $9.67 \mathrm{ab}$ & $66.27 \mathrm{ab}$ & $603.93 b$ & $25.16 b$ \\
\hline PKHT 2 & $6.27 \mathrm{bc}$ & $39.13 \mathrm{~cd}$ & $346.80 \mathrm{c}$ & $14.45 \mathrm{c}$ \\
\hline PKHT 9 & $10.27 \mathrm{a}$ & $73.28 \mathrm{ab}$ & $797.40 \mathrm{a}$ & $33.23 \mathrm{a}$ \\
\hline PKHT 10 & $10.53 a$ & $57.86 b c$ & $571.02 b$ & $23.79 b$ \\
\hline \multicolumn{5}{|c|}{ Kentang olahan } \\
\hline Atlantik & $3.10 \mathrm{c}$ & $34.52 d$ & $139.37 \mathrm{~d}$ & $5.81 \mathrm{~d}$ \\
\hline PKHT 4 & $7.33 \mathrm{ab}$ & $75.15 \mathrm{ab}$ & $697.22 \mathrm{ab}$ & $28.30 \mathrm{ab}$ \\
\hline PKHT 6 & $9.31 \mathrm{ab}$ & $79.90 \mathrm{a}$ & $718.04 \mathrm{ab}$ & $29.92 \mathrm{ab}$ \\
\hline Uji F & $* *$ & $* *$ & $* *$ & $* *$ \\
\hline
\end{tabular}

Keterangan: Angka yang diikuti huruf sama pada kolom tidak berbeda nyata pada DMRT taraf $\alpha=5 \%$, $\operatorname{tn}=$ tidak berpengaruh nyata pada taraf $5 \%, * *=$ berpengaruh nyata pada taraf $1 \%$

nyata dengan varietas Atlantik sebagai pembanding. Berdasarkan pengujian statistik pada Tabel 4 bahwa bobot total umbi kentang varietas Atlantik hanya sebesar 139.37 gram per lubang pertanaman. Bobot total yang tinggi pada klon PKHT 4 dan PKHT 6 mengindikasikan bahwa kedua klon tersebut dapat dijadikan substitusi varietas Atlantik serta meningkatkan produksi kentang olahan Indonesia.

Berdasarkan penggunaannya, semua klon yang ditargetkan untuk kentang sayur memiliki produktivitas tidak berbeda nyata dengan varietas pembanding Granola kecuali PKHT 2. PKHT 9 yang merupakan klon dengan produktivitas tertinggi dianggap dapat menjadiklon substitusi untuk varietas Granola yang selama ini mendominasi pasar kentang sayur Indonesia, yang ditanam hampir 80-90\% dari total pertanaman kentang Indonesia (Prabaningrum et al., 2015) karena memiliki produktivitas mencapai 25 ton ha ${ }^{-1}$ (Keputusan Menteri Pertanian, 1993) sedangkan PKHT 9 sudah mencapai 33.23 ton $\mathrm{ha}^{-1}$.

Atlantik sebagai varietas kentang komersial olahan yang dibudidayakan petani memiliki produktivitas terendah dalam pertanaman kali ini, yaitu 5.81 ton $\mathrm{ha}^{-1}$. Nilai ini cukup rendah dibandingkan dengan produksi dalam deskripsi varietas yang mencapai 8-20 ton ha ${ }^{-1}$ (Keputusan Menteri Pertanian, 2000). Rendahnya nilai produktivitas ini disebabkan oleh $P$. infestans yang menyerang Atlantik. Klon yang ditargetkan untuk kentang olahan memiliki produktivitas yang jauh lebih tinggi dibandingkan varietas pembanding, yaitu 28.30 ton $\mathrm{ha}^{-1}$ untuk PKHT 4 dan 29.92 ton ha-1 untuk PKHT 6. Dua klon ini dapat menjadi substitusi kentang olahan yang masih didominasi oleh varietas Atlantik karena memiliki produktivitas yang jauh lebih tinggi dan lebih tahan serangan penyakit.

Klon PKHT 9 adalah klon dengan umbi layak pasar terbanyak pada kentang sayur dan berbeda sangat nyata dengan Granola sebagai varietas pembanding. Total umbi per tanaman layak pasar pada PKHT 9 adalah 587.06 gram dan 24.46 ton ha $^{-1}$ umbi layak pasar tiap satu hektar (Tabel 4). PKHT 10 dan PKHT 2 memiliki umbi layak pasar yang tidak berbeda nyata dengan Granola sebagai varietas pembanding. Hal ini menunjukkan bahwa PKHT 9 dapat mengungguli Granola sebagai varietas komersial dan dapat dijadikan alternatif utama untuk pemilihan kentang sayur. PKHT 4 adalah klon terbaik pada kentang olahan dengan total umbi layak konsumsi per tanaman adalah 606.56 gram dan per hektar sebanyak 25.27 ton. PKHT 6 memiliki total umbi layak yang tidak berbeda nyata dengan PKHT 4. Kedua klon yang ditargetkan menjadi substitusi Atlantik pada kentang olahan ini memiliki umbi layak konsumsi yang berbeda sangat nyata dengan Atlantik sebagai varietas komersial. Rendahnya total umbi layak pada varietas Atlantik diindikasikan sebagai akibat dari serangan P. infestans.

Umbi layak pasar yang berhubungan dengan ukuran umbi dan tidak adanya terserang hama dan penyakit dipengaruhi oleh suplai nitrogen (N) dan kerapatan

Tabel 4. Umbi kentang layak pasar

\begin{tabular}{lcc}
\hline Klon & $\begin{array}{c}\text { Umbi layak pasar } \\
\text { per tanaman } \\
\left(\mathrm{g} \text { tanaman }^{-1}\right)\end{array}$ & $\begin{array}{c}\text { Umbi layak pasar } \\
\text { per hektar } \\
\left(\text { ton ha }^{-1}\right)\end{array}$ \\
\hline Kentang sayur & 363.25bc & $15.53 \mathrm{bc}$ \\
Granola & $191.98 \mathrm{~cd}$ & $7.99 \mathrm{~cd}$ \\
PKHT 2 & $587.06 \mathrm{a}$ & $24.46 \mathrm{a}$ \\
PKHT 9 & $362.66 \mathrm{bc}$ & $15.11 \mathrm{bc}$ \\
PKHT 10 & & \\
Kentang olahan & $58.50 \mathrm{~d}$ & $2.43 \mathrm{~d}$ \\
Atlantik & $606.56 \mathrm{a}$ & $25.27 \mathrm{a}$ \\
PKHT 4 & $453.20 \mathrm{ab}$ & $18.83 \mathrm{ab}$ \\
PKHT 6 & $* *$ & $* *$ \\
Uji F & & \\
\hline
\end{tabular}

Keterangan: Angka yang diikuti huruf sama pada kolom tidak berbeda nyata pada DMRT taraf $\alpha=5 \%, * *=$ berpengaruh nyata pada taraf $1 \%$ 
tanaman. Getie et al., (2015) melaporkan bahwa pemupukan $\mathrm{N}$ sebanyak $110 \mathrm{~kg} \mathrm{ha}^{-1}$ dan kerapatan tanaman sebanyak 6.67-8.00 tanaman $\mathrm{m}^{-1}$ merupakan ukuran yang tepat untuk menhasilakn total umbi layak pasar yang optimum. Pemupukan nitrogen yang terlalu sedikit $\left(54 \mathrm{~kg} \mathrm{ha}^{-1}\right)$ pada pertanaman dan intensitas hujan yang tinggi dianggap menjadi faktor utama pada rendahnya nilai umbi layak konsumsi terutama pada varietas komersial. Berdasarkan pertanaman ini dapat disimpulkan bahwa PKHT 9 dapat mengungguli Granola sebagai varietas kentang sayur dan PKHT 4 dan PKHT 6 dapat mengungguli Atlantik sebagai varietas kentang olahan dengan nitrogen yang minimum dan intensitas hujan yang tinggi.

\section{KESIMPULAN}

Berdasarkan hasil penelitian yang dilakukan dapat disimpulkan PKHT 4, PKHT 6, PKHT 9 dan PKHT 10 adalah klon-klon harapan kentang IPB yang memiliki produksi yang tinggi dan cukup stabil mengingat umbi bibit yang berasal dari G4 dibandingkan dengan varietas komersial. Berdasarkan penggunaan kentang PKHT 2, PKHT 9 dan PKHT 10 cocok untuk dijadikan kentang sayur dan klon PKHT 4 dan PKHT 6 cocok untuk dijadikan kentang olahan chips. Produksi klon-klon ini dapat mensubstitusi kebutuhan total kentang impor nasional.

\section{UCAPAN TERIMA KASIH}

Terima kasih disampaikan kepada Kementerian Ristekdikti yang telah mendanai penelitian ini melalui hibah Insinas tahun 2016 an. Awang Maharijaya.

\section{DAFTAR PUSTAKA}

Asgar, A., S.T. Rahayu, M. Kusmana, E. Sofiari. 2011. Uji kualitas umbi beberapa klon kentang untuk keripik. J. Hort. 21(1):51-59.

Budiman, A. 1999. Kebutuhan bahan baku untuk produksi olahan kentang PT. Indofood frito lay corp. Seminar Kebutuhan dan Peluang untuk Pengembangan PHT Kentang. Bogor. Maret 1999.

Getie, A.T., N. Dechassa, T. Tana. 2015. Response of potato (Solanum tuberosum L.) yield and yield components to nitrogen fertilizer and planting density at Haramaya, Eastern Ethiopia. Journal of Plant Sciences. 3(6):320328.

Hadisoeganda, A.W.W. 2006. Nematoda Sista Kentang: Kerugian, Deteksi, Biografi, dan Pengendalian Nematoda Terpadu. Balai Penelitian Tanaman Sayuran. Bandung.

Hamdani, J.S. 2009. Pengaruh jenis mulsa terhadap pertumbuhan dan hasil tiga kultivar kentang (Solanum tuberosum L.) yang ditanam di daratan medium. J. Agron. Indonesia 37(1):14-20.
Hidayat, Y.S. 2014. Karakterisasi morfologi beberapa genotipe kentang (Solanum tuberosum L.) yang dibudidayakan di Indonesia. Skripsi. Fakultas Pertanian. Institut Pertanian Bogor. Bogor.

[Kementan] Kementerian Pertanian. 2015. Impor komoditi pertanian berdasarkan negara asalsub sektor : hortikultura periode Januari sampai dengan Desember 2014. http://aplikasi.pertanian.go.id/ [9 November 2015].

[Kementan] Kementerian Pertanian. 2016. Produktivitas Kentang Menurut Provinsi. 2011, 2015, 2016. http://www.pertanian.go.id/Data5tahun/pdfHORTI2016/3.3 Produktivitas \%20 Kentang.pdf [31 Oktober 2016].

Keputusan Menteri Pertanian. 1993. Pelepasan Kentang Granola Kembang Sebagai Varietas Unggul.

Keputusan Menteri Pertanian. 2000. Pelepasan Kentang Atlantik Sebagai Varietas Unggul.

Maharijaya,A., M.Mahmud.,A.Purwito.2008.Ujiketahanan in vitro klon-klon kentang hasil persilangan kentang kultivar atlantic dan granola terhadap penyakit layu bakteri (Ralstonia solanacearum) dan busuk lunak (Erwinia carotovora). Bul. Agron. 36(2):133-138.

Maharijaya, A. 2014. Identifikasi beberapa tanaman Solanacea terhadap hama dan penyakit. Prosiding Seminar Nasional PERHORTI 2014. Malang 5-7 November 2014

Nonnecke, L.I. 1989. Vegetable Production. Van Norstrand Reinhold. Canada.

Pertamawati. 2010. Pengaruh fotosintesis terhadap pertumbuhan tanaman kentang (Solanum tuberosum L.) dalam lingkungan fotoautotrof secara in vitro. Jurnal Sains dan Teknologi Indonesia. 12 (1):31-37.

Prabaningrum, L., T.K. Moekasan, W. Adiyoga, N. Gunadi. 2015. Memilih varietas kentang yang tepat untuk budidaya kentang yang sehat. http:// balitsa.litbang. pertanian.go.id/ind/index.php/berita-terbaru/379memilih-varietas-kentang-yang-tepat-untukbudidaya-kentang-yang-sehat.html [31 Oktober 2016].

Purwanti, H. 2002. Penyakit hawar daun (Phytophthora infestans (Mont.) de Bary) pada kentang dan tomat: identifikasi permasalahan di Indonesia. Buletin AgroBio. 5(2): 67-72.

Purwito, A., G.A Wattimena. 2008. Kombinasi persilangan dan seleksi in vitro untuk mendapatkan kultivar unggul kentang. Jur.Ilmu Pertanian Indonesia. 13(3): 140-149. 
[PUSDATIN] Pusat Data dan Informasi. 2016. Konsumsi per kapita rumah tangga setahun menurut hasil susenas: sub sektor umbi-umbian. https://aplikasi2. pertanian. go.id/konsumsi/ tampil_susenas_kom2_th.php [10 November 2016].

Sofiari, E. 2009. Daya hasil beberapa klon kentang di Garut dan Banjarnegara. J.Hort. 19(2): 148-154.
Struik, P.C, S.G Wiersema. 1999. Seed Potato Technology. Wageningen Pers.. Wageningen.

Wulandari, A.N., S. Heddy, A. Suryanto. 2014. Penggunaan bobot umbi bibit pada peningkatan hasil tanaman kentang (Solanum tuberosum L.) G3 dan G4 varietas granola. Jurnal Produksi Tanaman. 2(1): 65-72. 